\title{
The Urgency of Harmonizing Competition Laws in Moving Towards the ASEAN Free Trade Area
}

\section{Hanif Nur Widhiyanti}

Faculty of Law, Universitas Brawijaya, Indonesia, Email: hanif.nur@ub.ac.id

\begin{tabular}{|c|c|}
\hline Article Info & Abstract \\
\hline $\begin{array}{l}\text { Keywords: } \\
\text { Competition, Competition Law, } \\
\text { ASEAN Economic Community. } \\
\text { How to cite: } \\
\text { Hanif Nur Widhiyanti, "The } \\
\text { Urgency of Harmonizing } \\
\text { Competition Laws in Moving } \\
\text { Towards the ASEAN Free Trade } \\
\text { Area," Fiat Justisia: Jurnal Ilmu } \\
\text { Hukum 14, No. } 1 \text { (2020): } 45-68 . \\
\text { 10.25041/fiatjustisia.v14no1.1749 }\end{array}$ & $\begin{array}{l}\text { ASEAN had created the ASEAN Regional Guidelines } \\
\text { on Competition Policy and Handbook on } \\
\text { Competition Policy and Law in ASEAN for Business } \\
\text { as guides for assessment of the behaviour of business } \\
\text { people in the industry and market. The Regional } \\
\text { Guidelines "only" help member countries in } \\
\text { increasing awareness of the importance of business } \\
\text { competition policies. The execution of business } \\
\text { competition is then left to the ASEAN member } \\
\text { country, to be in accordance with national business } \\
\text { competition policies. Meanwhile, the ASEAN } \\
\text { Economic Community will allow business people in } \\
\text { ASEAN countries to conduct business transactions } \\
\text { in whichever country they prefer. Without clear } \\
\text { regulations, businesspeople can freely carry out } \\
\text { cross-border transactions that can disrupt the } \\
\text { domestic market of each ASEAN member country. } \\
\text { Differences in regulatory substances and the } \\
\text { absence of competition law regulations in several } \\
\text { ASEAN member countries will undoubtedly become } \\
\text { a challenge for the application of competition laws } \\
\text { by businesspeople in the ASEAN regional market. } \\
\text { However, in relation to AFTA, the primary urgency } \\
\text { is instead the realization of imposing tariffs of O-5\% } \\
\text { by performing the harmonization of regulations in } \\
\text { the field of Customs and the removal of other forms } \\
\text { of Non-Tariff Barriers (NTBs). The removal of trade } \\
\text { barriers is one of the things that are also regulated } \\
\text { in competition law. This article is the result of } \\
\text { normative juridical research that analyzes the } \\
\text { differences in the substance of competition law in } \\
\text { several ASEAN countries along with their juridical } \\
\text { implications, to be able to evaluate the urgency of } \\
\text { harmonizing legal regulations on business } \\
\text { competition among the member countries of ASEAN. }\end{array}$ \\
\hline
\end{tabular}




\section{A. Introduction}

ASEAN has issued the ASEAN Regional Guidelines on Competition Policy as a guide to the regulations for general competition law for its member countries in the effort to form the ASEAN Economic Community (AEC). However, even now, ASEAN still has not possessed specific policies and institutions in the regulation and supervision of business activities that are carried out among its member countries. There also has not yet been any agreement in the policies of ASEAN regional business competition, which would become guidelines for policy application. The execution of business competition supervision is left to the member states, to be carried out according to national policies on business competition.

AEC is a single market for the Southeast Asia region, which has the aim to increase foreign investment in the region. For AEC to become a competitive region with a market that functions optimally, the regulations on competition need to be operational and effective. The fundamental aim of policies and laws on business competition is to create equality or equalisation of opportunities for all parties, though of different ownership. The application of competition regulations that forbid anti-competitive activities is an important way to facilitate liberalization as well as integrated markets and bases of production and to support the formation of a more competitive and innovative region. ${ }^{1}$

For the formation of a single market, the equalizing of legal principles becomes very important, and the same is true for business competition law. AEC will allow business people in ASEAN countries to be able to conduct business transactions in whichever country they prefer. The aim of AEC is indeed quite noble, which is to make it easier for business people to keep their enterprises running. However, this aim will become a detriment if not supported by laws regarding the competition that can outline clear regulations that apply globally to all businesspeople. According to Nawir Messi, without clear regulations, businesspeople may freely conduct cross-border transactions that may disrupt domestic markets, including in Indonesia.

Regarding this matter, for example, in Indonesia, collusive tendering is regulated by the rule of reason, while in Malaysia and Singapore, it is regulated as per se illegal. In Indonesia, tying agreements are considered as exclusive dealing and is regulated as per se illegal, while in Malaysia and Singapore, it is regulated under the stipulations of misuse of the dominant position and as such is regulated as rule of reason. Another example regards the merger control system, which in Indonesia is based on assets or turnover, while in Singapore and Vietnam is based on the level of market share. Regarding the timing of the notification, Indonesia adopts a post-notification system, while Singapore follows the system of the United Kingdom, in which the time that the notification is performed is entirely left to the parties of the merger. Only Indonesia penalizes parties in an alliance if they do not report

\footnotetext{
${ }^{1}$ ASEAN, ASEAN Economic Community Blue Print (Jakarta: ASEAN Secretariat, 2015), 75. 46
} 
the merger activity, while four other member nations with merger control can impose penalties if the merger that is performed results in anti-competitive behaviour in the market.

Other differences concern, for example, determining the scope of institutions that have authority in business competition, in particular in distributing functions and authority between the competent institution and the courts; some countries institute dual functions as investigator and adjudicator, and others divide responsibilities between authority (investigation) and the courts (for making verdicts).

When compared with business competition law in the European Union, there is a very fundamental difference, because, for all member countries of the European Union, business competition is regulated generally in Article 101 and Article 102 of the Treaty for the Functioning of the European Union (TFEU). Thus, the two articles apply for all member countries of the European Union. In the enforcement process for both articles, the European Union also has a special commission for a business competition that possesses legal authority for handling all cases of suspected anti-competition in all member countries of the European Union. Meanwhile, in ASEAN, each member country regulates its law on the competition by itself. The absence of general provisions has made the primary substance of competition laws among ASEAN countries "disharmonious", which indeed implements an ASEAN single market with a healthy climate of business competition even more difficult to be implemented. Based on the chronology detailed in the background, this is the problem raised in this research: what is the urgency of harmonizing legal regulations on competition law among countries in the Southeast Asia region, is heading towards the ASEAN Single Market?

\section{B. Discussion}

\section{The Challenge of Differences in Legal Substance Regulation}

The significant differences in legal substance among the member countries of ASEAN are determined by a number of factors that affected the formation of laws on the business competition during their composition, including its history. Several countries adopted the law and policy voluntarily, and others adopted because of certain goals such as legal reforms, ending an economic crisis, and the commitment to the consensus on free trade. Multifunctional authority to investigate as well as to deliver verdicts on competition law violations becomes a major challenge for competition agencies, particularly if their competence is doubted.

The above issues have certainly led to differences in the concepts of business competition laws. Some of the differing legal substance among others include, for example, regulation on the substance of anti-competitive actions, the nature of prohibitions on anti-competitive actions, the dominant 
position and the misuse of that dominant position, and regulation on mergers and acquisitions, as explained below:

\section{a. Scope of Businesspeople, Extraterritorial Doctrine, and Single Entity Doctrine}

In relation to the definition of "business people", the stipulations of Article 1 Number (5) of Indonesia follow the Exterritorial Doctrine, and implicitly and based on several decisions, the Business Competition Supervisory Commission (Komisi Pengawas Persaingan Usaha, KPPU) follows the concept of Single Economic Entity Doctrine, while Singapore and Malaysia follow the concept of effect doctrine. "Businesspeople" is a vital element to determine whether a person/enterprise may be considered to have violated Law No. 5 of the Year 1999. In-Law No. 5 of the Year 1999, it is mentioned that business people may consist of individual people or enterprise. This is as stated in Article 1 Number (5) of Law No. 5 of the Year 1999:

All individual persons or enterprise, whether in the form of a legal entity or not a legal entity that is established and residing or conducting activities in the legal territory of the Republic of Indonesia, whether on their own or together through an agreement, organizing various businesses in the field of economy.(Depan \& Sehat, n.d.)

The grouping of businesspeople in business competition law is very important in determining businesspeople for which the Business Competition Law of Indonesia may be applied. From the formulation of Article 1 Number (5), it is clear that Indonesia adopts the territorial principle for its business competition law. It means that for business people who establish or run businesses in Indonesia, Law No. 5 of the Year 1999 may be applied. ${ }^{3}$

In 2004, through Verdict Number 07/KPPU-L/2000, the KPPU for the first time indicted foreign businesses that were not established in Indonesia but conducted business activities in Indonesia, which are Goldman Sachs (Singapore) and Frontlite, Ltd. (Bermuda). Goldman Sachs was established based on the legal regulations of the Republic of Singapore and Frontlite, Ltd. of Bermuda, formerly named Frontlite AB, was established in 1985 and listed on the Stockholm Stock Exchange from 1989 to $1997 .^{4}$

In its verdict, the KPPU implicitly utilised the principle of Single Economic Entity Doctrine, which is a principle with the view that there is a relationship between parent companies and subsidiaries, where subsidiaries do not possess the independence to determine the policy direction of a

\footnotetext{
${ }^{2}$ Komisi Pengawas Persaingan Usaha, Kompetisi Menuju Pasar Bebas ASEAN, 42 ${ }^{\text {nd }}$ Edition (Jakarta: KPPU, 2013), 21.

3 Andy Tanaka, "Reformulation of Usage of Single Economic Entity Doctrine in Business Competition Law in Indonesia," Unpublished Thesis, Faculty of Law of the University of Brawijaya, (2016): 8.

${ }^{4}$ Verdict Number 07/KPPU-L/2000, p. 54. 
company as a single united economic entity. ${ }^{5}$ The consequence of the application of the Single Economic Entity Doctrine is that businesspeople may be held responsible for actions that may be conducted by other business people in an economic unit, even though the former operates outside the legal jurisdiction of business competition laws of a country, and thus business competition law can be considered extraterritorial. ${ }^{6}$

In the Temasek case in 2007, the KPPU explicitly applied the Single Economic Entity Doctrine. The case involved nine business people who were reported to have conducted violations of Law No. 5 of the Year 1999. In the case, Temasek Holdings as the parent company possessed the majority of shares in two companies who do business activities in the same field in the same related market, thus violating Article 27 Letter an of Law No. 5 of the Year 1999. Temasek Holdings possessed cross-ownership of shares in PT. Indosat Tbk. And PT. Telkomsel. Through Verdict Number 07/KPPUL/2007, KPPU applies the Single Economic Entity Doctrine again and explicitly mentions as such, to indict foreign businesspeople present outside the jurisdiction of Indonesia.

With the application of the Single Economic Entity Doctrine, there is an expansion of subjects of business competition law. The presence of enterprises and businesspeople does not have to be factually established and residing in Indonesia, but for business people who indirectly conduct business activities in Indonesia, as long as the businesspeople have relationships with companies who run business activities in Indonesia, they may be categorized as a subject of business competition law in Indonesia.

Next, in 2008, the KPPU also applied the Single Economic Entity Doctrine for the case of the Premier League broadcasting monopoly by Astro Group. In the case, three foreign businesspeople were indicted in violation of Law No. 5 of the Year 1999: Astro All Asia Networks, Plc (Malaysia); ESPN STAR Sports (Singapore); and All Asia Multimedia Network, FZ-LLC (United Arab Emirates). ${ }^{7}$ In 2010, in the case of the cartel by the pharmaceutical industry Amlodipine-class drug therapy, the KPPU also used the Single Economic Entity Doctrine to indict foreign parties that were involved. Four foreign parties were indicted in violation of Law No. 5 of the Year 1999, which were Pfizer Inc. (USA); Pfizer Overseas LLC (USA); Pfizer Global Trading (Ireland); and Pfizer Corporation Panama (Panama). ${ }^{8}$

Over its course, the use of the Single Economic Entity Doctrine, aside from generating many debates along with many experts, also regarding the differences of concept and scope about who might be called businesspeople in several countries, has caused many problems. As an example, in the

\footnotetext{
${ }^{5}$ Verdict Number 07/KPPU-L/2000, p. 36.

${ }^{6}$ Verdict Number 07/KPPU-L/2000, p. 37.

${ }^{7}$ Refer to KPPU Verdict Number 03/KPPU-L/2008, p. 1.

${ }^{8}$ Refer to KPPU Verdict Number: 17/KPPU-I/2010, p. 1.
} 
Temasek case, the Defendant in the case raised the issue regarding the jurisdiction of the KPPU in indicting using Law No. 5 of the Year 1999. The Defendant stated that "Temasek Group" does not have control over CoDefendant IX or even Indosat, and as such does not conduct business activities in Indonesia through the two companies. Co-Defendants V and VI mutually do not possess more than $41.94 \%$ of the shares of Indosat without special voting rights, including veto rights. Co-DefendantVIII only owns $35 \%$ of the shares of Co-Defendant IX, without voting rights or veto rights. ${ }^{9}$

Thus, regarding the stockholder who controls Indosat or Co-Defendant IX, it is the Government of Indonesia that possesses SeriesAshares with veto rights in Indosat and (through Telkom) possesses 65\% of the shares of CoDefendantIX. The Government of Indonesia also appoints the majority of Directors of Indosat (including the Chief Director) and selects the majority of Directors and Commissioners of Co-Defendant IX. The evidence put forward by the Plaintiff, Co-Defendants I to IX, and Indosat proved that the Plaintiff and/or "Temasek Group" does not have control of Co-Defendant IX or even Indosat. The consideration of the Defendants that the Plaintiff and/or "Temasek Group" has de facto controlled policies from Co-Defendant IX and Indosat is based on criteria that are faulty and ignores the existing evidence.

In addition, in the case of the Premier League broadcasting monopoly by Astro Group, All Asia Multimedia Networks, FZ-LLC (AAMN) put forward an objection on KPPU Verdict Number 03/KPPU-L/2008 to the State Court of Central Jakarta. Part of the objection is that AAMN is an outside party that resides and conducts business activities overseas. Thus, the single economic entity doctrine cannot be applied in this case.

As well, AAMN is not a stockholder of PT Direct Vision (PT DV) $)^{10}$ whether directly or indirectly. AAMN is merely a supplier for PT DV and does not have control over PT DV. ${ }^{11}$ All Asia Multimedia Networks, FZ-LLC $(\mathrm{AAMN})$, which in the case of the Premier League broadcasting monopoly by

\footnotetext{
${ }^{9}$ Supreme Court Verdict Number 496/K/Pdt.Sus/2008, pp. 11-12.

${ }^{10}$ PT Direct Vision (PT DV), in the case of the Premier League broadcasting monopoly by Astro Group having the status of Co-Defendant $\mathrm{I}$, is an enterprise in the legal entity form of a corporation (Perseroan Terbatas) established based on the legal regulations of the Republic of Indonesia, with statutes that were last changed based on Act Number 119 by Sutjipto, S.H. as the notary. Its shares are possessed by PT Ayunda Prima Mitra (49\%) and Silver Concord Holdings Limited (51\%), wherein PT Ayunda Prima Mitra is owned by PT Broadband Multimedia, Tbk (now PT First Media, Tbk), which is one of the subsidiaries of Lippo Group, currently residing at Citra Graha Building Floor 9, Jalan Jenderal Gatot Subroto Kavling 35-36 Jakarta 12950, Indonesia. Its business activity is the provision of paid television based on the Directorate General of Post and Telecommunications Notice Number 14 February 2005 regarding the permits of providing multimedia telecommunication services as paid television, and conducts business activities from February 28, 2006 in the region of Indonesia using the trademark "ASTRO".

11 Anonymous, AAMN Objects to the KPPU Verdict: AAMN Considers KPPU to Have Misapplied the Law in the Premier League Broadcasting Rights Case, March 29, 2016, http://www.hukumonline.com/berita/baca/hol20246/aamn-ajukan-keberatan-putusan-kppu. 50
} 
Astro Group has the status of Co-DefendantIV, is an enterprise in the legal entity form of a company established in April 2006 in Dubai, United Arab Emirates. Its shares are $100 \%$ fully owned by Astro All Asia Networks, Plc (AAAN), which currently resides at Dubai World Center Floor 6, Dubai, United Arab Emirates, with a branch office in All Asia Broadcast Centre, Technology Park Malaysia, Lebuhraya Puchong Sungai Besi, 57000 Kuala Lumpur, Malaysia. Its primary business activities are to obtain content and create television channels in Indonesian and Malaysian languages to be supplied to paid television operators operated by Astro, as PT Direct Vision (PT DV) in Indonesia, Measat Broadcast Network Systems Sdn. Bhd (MBNS) in Malaysia, and "Kristal Astro" di Brunei Darussalam. Its secondary activity is the procurement of decoders to be supplied to PTDV in Indonesia.

In the case of the amlodipine pharmacy industry cartel, Pfizer Indonesia, which did not participate in the Supply Agreement created by Pfizer Overseas LLC with PT Dexa Medica, also questioned the use as well as the principle of Single Economic Entity Doctrine. Pfizer Indonesia rejected the theory posed by the KPPU regarding Pfizer Group in relating the agreement with Pfizer Indonesia. Pfizer Indonesia had the opinion that there was no legal basis for the KPPU to pose the theory of the Pfizer Group. ${ }^{12}$ In addition, Pfizer Indonesia stated that there was no legal basis for Single Economic Entity in the legal stipulations that apply in Indonesia. ${ }^{13}$

From the above explanation, inconsistencies regarding the concept and the scope of businesspeople in several countries including ASEAN member countries have created many problems and resulted in juridical implications in the effort of business competition law enforcement; as such, it becomes urgent to find solutions immediately.

\section{b. Regarding Regulation of Legal Substance of Anti-Competitive Actions, Prohibition of Anti-Competitive Actions, and Related Evidence}

\section{1) Cartel as an anti-competitive act}

All countries that regulate competitive law will always regulate cartels. A cartel is a form of an agreement by a number of free companies. The aim is clearly to affect products and the marketing of a commodity to obtain a monopolistic advantage. According to the Black Law Dictionary, "Cartel is a combination of procedures or sellers that join together to control products, production, or price. Cartel is also an association of firms with a common interest. It seeks to prevent extreme or unfair competition, allocates markets, or share knowledge."14

\footnotetext{
${ }^{12}$ KPPU Verdict Number 17/KPPU-I/2010, p. 97.

${ }^{13}$ Ibid., p. 132.

${ }^{14}$ KPPU Verdict Number 17/KPPU-I/2010, pp. 9\&206.
} 
Cartel may be categorized in a narrow and broad scope. Narrowly, the cartel is a group of businesspeople who compete with one another, but they only agree to cooperate to establish prices, enabling them to obtain profits above a suitable level.

Meanwhile, cartel broadly is an agreement between two or more business people who conduct harmonization of behaviours or actions to cover up competition among them in the market by dividing marketing territory, distributing consumers, and fixing prices. As such, the most commonly occurring kind of cartel among businesspeople are price-fixing agreements, collusive tendering, agreements of market area division or consumer distribution, and agreements to limit production quota. ${ }^{15} \mathrm{Next}$, according to the OECD, the cartel is a formal agreement among companies in an oligopolistic industry. Members of a cartel can make agreements, for example, on price, output, limited marketing area, consumer distribution, profit sharing, or any combination of these. ${ }^{16}$

Through cartels, producers can establish higher prices and obtain incredible profits. The Government of Australia has even classified cartel, which includes price-fixing, as a "white-collar crime", as a criminal act that is often characterized as having no victim like crimes in general, instead of bringing about hefty fees on market participants, as stated by the Australian Competition and Consumer Commission (ACCC). Thus, one kind of legal regulation is to ensure the organization of a free and fair market, which includes the prevention of price-fixing by businesspeople.

Competition regulations in Malaysia and Singapore no longer use the terminology of "cartel"; they instead detail the several ways in which cartels may be realized:

a) Singapore, Competition Act of 2004, Section2:

Agreements between undertakings, decisions by associations of undertakings or concerted practices which have as their object or effect the appreciable prevention, restriction or distortion of competition within Singapore will fall within the scope of the Section 34 Prohibition unless they are excluded under the Third Schedule or fall within a category specified in a block exemption order. Any provision in the Act expressed to apply in relation to an 'agreement' is taken as applying equally, with

\footnotetext{
${ }^{15}$ R. Shyam Khemani, A Framework for the Design and Implementation of Competition Law and Policy (Paris: The World Bank-OECD, 1999), 21.

16 "A cartel is a formal agreement among firms in an oligopolistic industry. Cartel members may agree on such matters as prices, total industry output, market shares, allocation of customers, allocation of territories, bid-rigging, establishment of common sales agencies, and the division of profits or combination of these", Glossary of Statistical Terms, http://stats.oecd.org/glossary/detail.asp?ID=3159, accessed August 1, 2010. Also refer to the OECDRecommendation of the Council Concerning Effective Action Against Hard Core Cartels, adopted by the council in meeting session 921 on March 25, 1998 [C/M (98) 7/PROV]; see also R. Shyam Khemani, Op.Cit., 21. 
the necessary modifications, in relation to a decision by an association of undertakings or a concerted practice.

b) Malaysia, Competition Act of 2010, Section 4:

(1) A horizontal or vertical agreement between enterprises is prohibited insofar as the agreement has the object or effect of significantly preventing, restricting or distorting competition in any market for goods or services.

(2) Without prejudice to the generality of subsection (1), a horizontal agreement between enterprises which has the object to:

a. fix, directly or indirectly, a purchase or selling price or any other trading conditions;

b. share market or sources of supply;

c. limit or control- (i) production; (ii) market outlets or market access; (iii) technical or technological development; or (iv) investment; or

d. perform an act of bid rigging,

is deemed to have the object of significantly preventing, restricting, or distorting competition in any market for goods or services.

Meanwhile, in Indonesia, cartels are regulated in stipulations of Article 11 of Law No. 5 of the Year 1999: "Businesspeople are forbidden to create agreements with competing for business people that are intended to affect prices by regulating expenses and/or marketing". Article 11 is only limited to agreements that establish the sale of certain goods with the intent of achieving certain desired prices. The use of the "cartel" term in Article 11 seemingly indicates that cartels are narrowly interpreted, although in reality the indications of cartels are regulated in several other stipulations, among them Article 5, Article 9, and Article 22 of Law No. 5 of the Year 1999, as indicated by the following table:

Table 1: Indications of the cartel in several regulatory in Law Number 5 of Year 1999

\begin{tabular}{|c|c|c|c|}
\hline No. & Article & Substance & Category \\
\hline 1 & $\begin{array}{l}\text { 5: Price } \\
\text { Fixing }\end{array}$ & $\begin{array}{l}\text { a. Businesspeople are forbidden } \\
\text { to create agreements with } \\
\text { competing business people to } \\
\text { establish prices on certain } \\
\text { goods and/or services that must } \\
\text { be paid by consumers or } \\
\text { subscribers in the same related } \\
\text { market. } \\
\text { b. The stipulations, as expressed } \\
\text { in paragraph (1) do not apply } \\
\text { to: }\end{array}$ & Price cartel \\
\hline
\end{tabular}




\begin{tabular}{|c|l|l|l|}
\hline & \multicolumn{1}{|c|}{$\begin{array}{c}\text { a. agreements created in a joint } \\
\text { venture; or } \\
\text { b. agreements created based on } \\
\text { applicable legal regulations. }\end{array}$} & Area cartel \\
\hline 2. & $\begin{array}{l}\text { 9: Area } \\
\text { Distribution }\end{array}$ & $\begin{array}{l}\text { Businesspeople are forbidden to } \\
\text { create agreements with competing } \\
\text { businesspeople with the intent to } \\
\text { divide the marketing area or market } \\
\text { allocation of goods and/or services, } \\
\text { thus possibly resulting in } \\
\text { monopolistic and/or unhealthy } \\
\text { business competition practices. }\end{array}$ & \\
\hline 3. & $\begin{array}{l}\text { 22: } \\
\text { Collusive } \\
\text { Tendering }\end{array}$ & $\begin{array}{l}\text { Businesspeople are forbidden to } \\
\text { ally with other parties to regulate } \\
\text { and/or determine the winner of a } \\
\text { tender, thus possibly resulting in } \\
\text { unhealthy business competition. }\end{array}$ & tendering \\
\hline
\end{tabular}

Source: Primary Legal Materials, processed

\section{2) The Nature of Cartel Prohibitions}

The nature of prohibiting anti-competitive acts may be classified as per se illegal or rule of reason. The concept of per se illegal is the statement that certain agreements or business activities violate the law, without further proof of the effects of those agreements or business activities. Events that are considered per se illegal usually cover collusive price-fixing on certain products, as well as the regulation of resale value. ${ }^{17}$ In other words, the focus of competition law paradigm is that if the prohibition is absolute, then the concept is per se illegal, but if it is supplementary, then it will be decided based on the consideration of reasonableness ${ }^{18}$ from the reasons.

\footnotetext{
${ }^{17}$ R. Sheyam Khemani and D. M. Shapiro, Glossary of Industrial Organisation Economics and Competition Law, (Paris: OECD, 1996), 51, in Lubis, Andi Fahmy. Anggraini, A.M. Toha, Tri Kurnia. Kagramanto, L. Budi. Hawin, M. Sirait, Ningrum Natasya. Sukarmi. Maarif, Silalahi, Syamsul Udin, Persaingan Usaha antara Teks dan Konteks, (Indonesia: Published and Printed with Support of Deutsche Gesellschaft für Technische Zusammenarbeit (GTZ) GmbH, 2009), 55.

${ }^{18}$ The term "reasonableness" was first used in the case of Mitchel vs. Reynolds in 1711 by Lord Macclesfield, whose legal opinion actually refers to the verdict of Dyer's case. The case of Mitchel vs. Reynolds concerns a baker in doing his business and an established agreement that forbids the baker to conduct his business for a certain time and in a certain area (within a period of five years). An agreement such as this is considered to violate competition, divide regions, and limit the entry into a market. Dyer's case concerns when Dyer was forbidden to conduct business related to his expertise for six months as an effort to pay debts. Efforts such as these that are written in agreements, in connection to competition, is considered as an effort to impede competition. Ningrum Natasya Sirait, Hukum Persaingan di Indonesia (Medan: Pustaka Bangsa Press, 2004), p. 75. 
Meanwhile, the concept of the rule of reason is an approach used by a business competition supervisory authority to conduct evaluations regarding the effects of certain agreements or business activities, in order to determine whether the agreements or activities impede or support competition. ${ }^{19}$ Black's Law Dictionary defines a rule of reason as the following: ${ }^{20}$

"Under 'rule of reason' test for determining whether alleged acts violated $\$ 1$ the Sherman Anti-Trust Act (15 U.S.C.A. \$1), which declares conspiracies in restraint of trade to be illegal, fact-finder must weigh all circumstances of the case to decide whether practice unreasonably restrains competition and the test requires that plaintiff show anticompetitive effects, or actual harm to competition, and not whether the practices were unfair or tortious"

Regarding the nature of prohibitions, hardcore cartels, in general, are established to be prohibited per se illegal, such as in the regulations implemented in Singapore ${ }^{21}$ and Malaysia, ${ }^{22}$ but this is not the case with Law Number 5 of the Year 1999. Differences in cartel regulations, including the nature of the prohibition, makes out Indonesia to be a "potential market" in a

19 "The rule of reason is a legal approach by competition authorities or the courts where an attempt is made to evaluate the pro-competitive features of a restrictive business practice against its anticompetitive effects in order to decide whether or not the practice should be prohibited. Some market restrictions which prima facie give rise to competition issues may on further examination be found to have valid efficiency-enhancing benefits. For example, a manufacturer may restrict supply of a product in different geographic markets only to existing retailers so that they earn higher profits and have an incentive to advertise the product and provide better service to customers. This may have the effect of expanding the demand for the manufacturer's product more than the increase in quantity demanded at a lower price. The opposite of the rule of reason approach is to declare certain business practices per se illegal, that is, always illegal are per se illegal.", in the Glossary of Industrial Organisation Economics and Competition Law, compiled by R. S. Khemani and D. M. Shapiro, Commissioned by the Directorate for Financial, Fiscal and Enterprise Affairs, OECD, (1993), August 1, 2011. http://stats.oecd.org/glossary/detail.asp?ID=3305.

${ }^{20}$ Bryan A. Graner, (2004), Black's Law Dictionary, p. 1332.

${ }^{21}$ Section 34(2) of the Act provides an illustrative but not exhaustive list of agreements which may be prohibited. These include agreements which (a) directly or indirectly fix purchase or selling prices or any other trading conditions; (b) limit or control production, markets, technical development or investment; (c) share markets or sources of supply; (d) apply dissimilar conditions to equivalent transactions with other trading parties, thereby placing them at a competitive disadvantage; or (e) make the conclusion of contracts subject to acceptance by the other parties of supplementary obligations which, by their nature or according to commercial usage, have no connection with the subject of such contracts.

${ }^{22}$ Section 4 (2) :

Without prejudice to the generality of subsection (1), a horizontal agreement between enterprises which has the object to :

a. fix, directly or indirectly, a purchase or selling price or any other trading conditions;

b. $\quad$ share market or sources of supply;

c. limit or control- (i) production; (ii) market outlets or market access; (iii) technical or technological development; or (iv) investment; or

d. perform an act of bid rigging,

is deemed to have the object of significantly preventing, restricting, or distorting competition in any market for goods or services 
negative connotation, particularly for actors of regional cartel sand collusive tendering.

\section{3) The Proving of Cartels}

As has been previously explained, in the execution, cartel actors often do away with all forms of direct agreements and communication, and instead, conduct meetings in secret. ${ }^{23}$ The core point of a cartel is that there is a commitment from the members of a cartel to follow the agreements that they have made.

As such, in their developments, cartels are often conducted in secret and are thus very hard to be detected by law enforcers. Meanwhile, although the amount of loss by consumers due to the presence of cartels is not known, the occurring tendency shows that excesses of prices due to cartels is quite large. It is because the prices from the cartel agreement are prices that are higher than prices that would be created due to competition. The experience of various countries shows that cartel prices can reach $400 \%$ above the market price. Therefore, it is no wonder that loss due to cartels can reach billions or even trillions of rupiahs. ${ }^{24}$

The fact that cartels are hard to detect and the consequences of cartels that very much cause loss make the law enforcement process on cartel practices urgent to be performed. The availability of evidence mainly causes difficulties in the enforcement process. It is because business people engaged in cartels no longer live in ancient times where every agreement must be verbally written on paper, stamped, and signed.

In the effort indict cartels amidst the impossibility of finding hardcore evidence, an evolution in evidence came about, called "indirect evidence". The network of competition supervisory institutions around the world created a new method to uncover violations of prohibitions by cartels, by using indirect evidence as an alternative to conventional direct evidence. Indirect evidence includes communicative evidence and economic evidence. In addition, there needs to be a "plus" factor in strengthening indirect evidence.

Several ASEAN countries do not have problems with any evidence, whether direct evidence or indirect evidence, but not Indonesia. From 2010 to 2015 alone, there were several KPPU verdicts related to cartels that were annulled by state courts, with the uniform reason that the evidence presented by the KPPU was considered not strong enough because no direct evidence was used and only indirect evidence was involved.

Several KPPU verdicts regarding suspected cartels were annulled by the State Courts and/or the Supreme Courts with the reason that the State Courts and Supreme Court do not recognize the use of indirect evidence as

\footnotetext{
${ }^{23}$ Jhonny Ibrahim, (2007), Business Competition Law: Philosophy, Theory, and Implications of Implementation in Indonesia, Malang: Bayu Media, pp. 230-231.

${ }^{24}$ Guide on Article 5 on Price Agreements 
evidence. ${ }^{25} \mathrm{KPPU}$ Chief Syarkawi Rauf admits that indirect evidence is often cast aside by courts "because many judges do not understand clearly about circumstantial evidence." ${ }^{26}$ In addition, while judges confirm that the prices present in the market is a fact, yet so do they with meeting minutes found by investigators; both are facts. However, the problem becomes how to relate those minutes with the prices present in the market, without going through analysis by economic experts. It is a matter that Indonesian courts cannot yet accept. $^{27}$

The following is a list of KPPU verdicts on suspected cartels that were annulled by State Courts and/or the Supreme Court:

Table2: KPPU verdicts on suspected cartels that were annulled by State Courts and/or the Supreme Court:

\begin{tabular}{|c|c|c|}
\hline No. & Verdict & Notes \\
\hline 1. & $\begin{array}{l}\text { KPPU Verdict } \\
\text { 25/KPPU-I/2009 on the } \\
\text { Application of Fuel Surcharge } \\
\text { in the Domestic Airplane } \\
\text { Services Industry }\end{array}$ & $\begin{array}{l}\text { The Defendants - PT Garuda } \\
\text { Indonesia, PT Sriwijaya Air, PT } \\
\text { Merpati Nusantara Airlines, PT } \\
\text { Mandala Airlines, PT Travel } \\
\text { Express Aviation Service, PT Lion } \\
\text { Mentari Airlines, PT Wings Abadi } \\
\text { Airlines, PT Metro Batavia, and PT } \\
\text { Kartika Airlines - filed an appeal to } \\
\text { State Court, which then annulled the } \\
\text { KPPU verdict with the reason that } \\
\text { the proving of cartel was conducted } \\
\text { merely with indirect evidence and } \\
\text { not using direct evidence. }\end{array}$ \\
\hline 2. & $\begin{array}{l}\text { Case Number 17/KPPU-I/2010 } \\
\text { on Suspected Violations of } \\
\text { Article 5, Article 11, Article 16, } \\
\text { Article } 25 \text { Paragraph (1) Letter } \\
\text { a of Law Number } 5 \text { of the Year } \\
1999 \text { in the Amlodipine-Class } \\
\text { Therapy Pharmacy Industry }\end{array}$ & $\begin{array}{l}\text { a. The council of judges affirm } \\
\text { that they agree with the UI } \\
\text { statistical economics expert } \\
\text { Anton Hendranata, who stated } \\
\text { that there was no same trend of } \\
\text { rising prices of the two } \\
\text { hypertension medications by PT } \\
\text { Pfizer Indonesia and PT Dexa } \\
\text { Medica. "There was no same } \\
\text { trend of rising prices. The } \\
\text { Plaintiff (KPPU) also did not }\end{array}$ \\
\hline
\end{tabular}

\footnotetext{
${ }^{25}$ Happy Rayna Stephany, Courts Are Still “Allergic" to Indirect Evidence, November 21, 2019. http://www.hukumonline.com/berita/baca/lt5398841721bba/pengadilan-masih-alergidengan-iindirect-evidence-i.

${ }^{26}$ November 21, 2019. https://babe.news/id-id/read/9342514/bukti-tidak-langsung-yang-bikinkppu-tidak-bertaji.

${ }^{27}$ Ibid.
} 


\begin{tabular}{|c|c|c|}
\hline & & 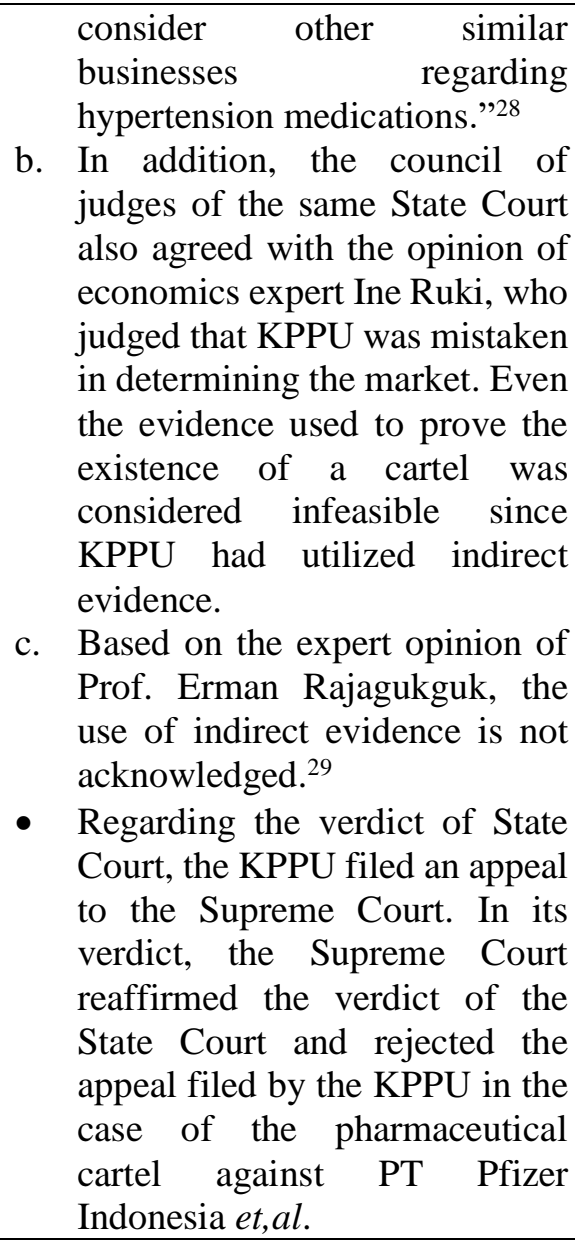 \\
\hline 3. & \begin{tabular}{llr} 
KPPU Verdict & \multicolumn{2}{c}{ Number } \\
$24 /$ KPPU-I/2009 & on the \\
Cooking Oil Cartel & &
\end{tabular} & $\begin{array}{l}\text { a. The State Court of Central } \\
\text { Jakarta stated that the evidence } \\
\text { provided by the KPPU was } \\
\text { considered not strong enough } \\
\text { since there was no direct } \\
\text { evidence to incriminate the } \\
\text { cartel actors; in its verdict, the } \\
\text { State Court annulled the KPPU } \\
\text { verdict. } \\
\text { b. KPPU then filed an appeal on } \\
\text { the court verdict that refuted the }\end{array}$ \\
\hline
\end{tabular}

${ }^{28} \mathrm{Ibid}$.

${ }^{29} \mathrm{Ibid}$.

${ }^{30}$ November 21, 2019. http://nasional.kontan.co.id/news/ma-tolak-putusan-kppu-atas-kartelminyak-goreng. 


\begin{tabular}{|l|l|}
\hline & $\begin{array}{l}\text { verdict of the cartel. } \\
\text { Unfortunately, the State Court } \\
\text { also rejected the appeal by } \\
\text { KPPU with the same reason as } \\
\text { the State Court. }\end{array}$ \\
\hline
\end{tabular}

Source: Primary Legal Materials, processed

The above condition is worsened wherein with Law Number 5 of the Year 1999, the KPPU does not possess the authority to confiscate documents or to search for them; as well, the formality of usage of evidence tends to be conventional, covering witness statements, expert statements, documents or letters, instructions, and statements of business people. Here lies a very great challenge for KPPU in proving violations by cartels, whether in the form of agreements of price-fixing cartels, production quota cartels, and regional cartels, since generally in the process of proving, the KPPU does not find written agreements as the starting point of the intent of parties in creating a cartel. In its application, the proving of an unwritten deal can be done through evidence of agreement as found in meeting agendas in the form of minutes or notes. In this case, even if there were written agreements, the KPPU often has trouble in obtaining the data. The difficulty in obtaining evidence of agreements is caused by several issues, including uncooperative business people who refuse to provide data; on the other hand, there is an absence of KPPU authority to search and confiscate the required documents as evidence. ${ }^{31}$

The KPPU has done in using indirect evidence or circumstantial evidence to prove cartels can be argued. In addition to the reason that the characteristics of cartels are difficult to prove formally, indirect evidence or circumstantial evidence has been regulated in the Guide to Article 5 of Law Number 5 of the Year 1999 as a form of evidence that indirectly states that there is agreement on price, supply, or regional division. Whatever the case, it seems that the State Courts still firmly hold the stipulations of Article 8 of Supreme Court of the Republic of Indonesia Regulation Number 03 of the Year 2005. ${ }^{32}$ The choice becomes difficult. If the regulations in Article 8 above were rigidly applied, then there would be many cases of cartels that cannot be proven by the KPPU if direct evidence is not available, and the case is only based on indirect evidence in the form of communicative evidence and economic evidence categorized as initial evidence.

\footnotetext{
${ }^{31}$ A. M. Tri Anggraini, "The Mechanisms of Detecting and Uncovering Cartels in Competition Law," Faculty of Law Paper, University of Indonesia, (2011): 21.

${ }^{32}$ Hanif Nur Widhiyanti, "The Use of Indirect Evidence in Proving Suspected Violations of Law Number 5 of Year 1999 in the Perspective of Supreme Court Regulations, Number 3 of Year 2005," DPP/SPP Research, Faculty of Law, University of Brawijaya, (2017): 31.
} 
Regarding this initial evidence, both Law Number 5 of the Year 1999 and Commission Regulation Number 1 of the Year 2010 neither regulates nor explains about initial evidence as well as how this evidence is used in proving by the KPPU.

Meanwhile, in the development of case handling, specifically cases of cartels in different parts of the world, efforts to prove the presence of cartels are not only done through direct or hard evidence, but also through other methods of determining through indirect or circumstantial evidence. It is occurring because direct evidence is becoming harder to find, as the presence of competition supervision institutions has become a considered factor; thus, matters related to direct evidence has been avoided by businesspeople. The development of handling cases of price-fixing in various parts of the world is also attempted not only through direct or hard evidence, but also through other methods of proving through indirect or circumstantial evidence. In the same way, direct evidence has become harder to find as the presence of competition supervision institutions has become a considered factor. ${ }^{33} \mathrm{As}$ such, Indonesia again will become a "potential market" in a negative sense regarding cartels, because so long as the effects of the two cartels cannot be proven, then a businessperson or a group of them cannot be punished by Law Number 5 of the Year 1999.

\section{4) Regarding Notifications of Acquisitions and Mergers}

It is undeniable that the merging of businesses and acquisition of shares is one of the strategies to increase company efficiency in conducting expansion to face the challenge of globalisation, which has been massively progressing in the past several years. ${ }^{34}$ For consumers, the merging of businesses and the acquisition of shares, on the one hand, may provide benefits if the gained efficiency translates to price reductions and increased quality of goods and/or services. Yet on the other hand, this strategy may also increase market concentration, which if not handled well may put consumers at a disadvantage later on. ${ }^{35}$

Countries in Southeast Asia have decided to form an integrated economy in 2015, among others through investment, goods, services, free market for labour, the formation of a competitive area, and so on. To face this challenge, countries that are a part of ASEAN decided to introduce business competition policies to overcome the potential of market concentration and unhealthy competitive behaviours in the nation, which is expected to be able to prepare them to face the economic integration. ${ }^{36}$ For that, regulations regarding the merging of businesses and acquisition of shares become essential in the

\footnotetext{
${ }^{33}$ Ibid., 32.

${ }^{34}$ Deswin Nur, "The Unique Merger Regulations in Southeast Asia," Jurnal Kompetisi 24, (2010), 21.

${ }^{35}$ Ibid.

${ }^{36}$ Ibid. 
prevention of the market concentration potential that may impede the execution of this integration. The flow of investment among fellow ASEAN countries have reached 4.4 billion USD at the end of 2009, most of which belong to Singapore (46\%), Indonesia (31\%), and Thailand (13\%). ${ }^{37}$ This indicates that investment in these three countries in Southeast Asia is quite dominant, which makes various investment regulations (in particular regarding the merging of businesses and acquisition of shares) an important factor in maintaining a market structure that is efficient and competitive.

Regionally, statistics have shown that during the past semester in 2010, 36 merger agreements have occurred in Southeast Asia, with a value of 7.1 billion USD. It is quite optimistic in comparison to 77 merger agreements with a market value of 14.5 billion USD in 2009. Most of the merger activities in Southeast Asia have taken place in the sectors of natural resources and energy, finance and consumer, and manufacturing. Interestingly, most of the investment in Southeast Asia came from China, making up 29\% of the total merger activities in Southeast Asia. This fantastic figure exceeded the United States as the record holder from the previous year. Specifically, most merger activities in Southeast Asia were conducted in Singapore, amounting to onethird of the portion of total transactions in Southeast Asia (with a value of 4.2 billion over the past year per June), with manufacturing as the sector with the greatest frequency of mergers. ${ }^{38}$

Regarding the regulations that control business competition and mergers, currently, out of the ten member countries of ASEAN, only five of them (Indonesia, Singapore, Thailand, Vietnam, and Malaysia) possess laws on business competition. Malaysia itself had only introduced its business competition law in 2010, which became effective in 2012. Five other countries still rely on the sector approach and are preparing the aforementioned policy. Regulations on business mergers and acquisitions have several differences regarding various aspects, specifically regarding coverage, nature, approach, financing, and related sanctions. The following is a brief table that summarizes the condition of merger regulations in ASEAN:

Table3: Merger Regulations in ASEAN Member Countries

\begin{tabular}{|l|l|c|c|c|c|l|}
\hline No. & Country & $\begin{array}{c}\text { Merger } \\
\text { Regulatio } \\
\text { ns }\end{array}$ & Coverage & Notification & $\begin{array}{c}\text { Sanctions } \\
\text { for Not } \\
\text { Notifying }\end{array}$ & $\begin{array}{c}\text { Feeling } \\
\text { Fee }\end{array}$ \\
\hline 1. & $\begin{array}{l}\text { Brunei } \\
\text { Darussalam }\end{array}$ & Absent & - & - & - & - \\
\hline 2. & Cambodia & Absent & - & - & - & - \\
\hline 3. & Indonesia & Present & $\begin{array}{c}\text { Consolidati } \\
\text { on, Merger, }\end{array}$ & Required & Present & Absent \\
\hline
\end{tabular}




\begin{tabular}{|c|l|l|l|l|l|l|}
\hline & & & $\begin{array}{l}\text { Share } \\
\text { acquisition }\end{array}$ & & & \\
\hline 4. & Laos & Present & Merger & Optional & Absent & Absent \\
\hline 5. & Malaysia & Absent & \multicolumn{1}{|c|}{-} & - & - & \\
\hline 6. & Myanmar & Absent & - & - & - & \\
\hline 7. & Filipina & $\begin{array}{l}\text { Present } \\
\text { (sector) }\end{array}$ & $\begin{array}{l}\text { Consolidati } \\
\text { on, Merger }\end{array}$ & Required & Present & Present \\
\hline 8. & Singapore & Present & $\begin{array}{l}\text { Consolidati } \\
\text { on, Share } \\
\text { acquisition, } \\
\text { Asset } \\
\text { acquisition, } \\
\text { Joint } \\
\text { venture }\end{array}$ & Optional & Absent & Present \\
\hline 9. & Thailand & Present & $\begin{array}{l}\text { Consolidati } \\
\text { on, Share } \\
\text { acquisition, } \\
\text { Asset } \\
\text { acquisition }\end{array}$ & Required & Absent & Absent \\
\hline 10. & Vietnam & Present & $\begin{array}{l}\text { Consolidati } \\
\text { on, Merger, } \\
\text { Acquisition } \\
\text { (partial/tota } \\
\text { 1), Joint } \\
\text { venture, } \\
\text { Other } \\
\text { forms }\end{array}$ & Required & Present & Absent \\
\hline
\end{tabular}

Source: Primary Legal Materials, processed

The ten ASEAN member nations, only six countries possess regulations on mergers, whether under its competition law or present in sector regulations. Five countries (Laos, Indonesia, Singapore, Thailand, and Vietnam) possess merger regulations under competition law, while the Philippines still relies on sector merger (in the finance sector). ${ }^{39}$

Indonesia itself at present has possessed special regulations on business mergers and acquisition, which is Government Regulation No. 57/2010 on Business Consolidation and Merger and Takeover of Shares that May Cause Monopolistic Practices and Unhealthy Business Competition. The regulations, which are the execution of Article 28 of Law No. 5/1999 on the Prohibition of Monopolistic Practices and Unhealthy Business Composition is the starting point for the application of a quite significant merger regime in Indonesia. ${ }^{40}$ 
This regulation requires that business people who are about to perform a merger are to report the plan after the merger is approved by law. The same requirement is also adopted by two other countries, Thailand and Vietnam. What is interesting is that Singapore instead does not require notifications on merger activities carried out in the country. It is a unique fact when considering that the most significant market capitalization in Southeast Asia occurs in the city-state. In considering coverage, the above table indicates that Vietnam has the most complete coverage of mergers, including business consolidation, business merging, acquisition, joint venture, as well as other forms of integration. This will certainly be to the benefit of the country in facing competition in the later era of free trade. ${ }^{41}$

Meanwhile, merger regulations in Indonesia are limited to consolidation, merger, and share acquisition. Asset acquisition is not included in the coverage of Indonesia and supervision is only on the increase in control by businesspeople through ownership of shares. To guarantee the creation of a competitive market structure, the obligation of notification by businesspeople regarding merger efforts is very much necessary. Out of the four countries that possess regulations of mergers in their business competition regulations, effectively only Indonesia, Thailand, and Vietnam that requires notifications on merger activities. However, Thailand itself in one way has not been able to obligate the notification. It is because its business competition law does mandate the obligation of notification, but only if it fulfils a certain threshold. ${ }^{42}$

\section{Single Market and Free Trade Area in the Scope of ASEAN}

Economic integration among countries in a regional area, which may be in the formation of a Single Market, Free Trade Area, or Customs Union, is one of the consequences of the liberalization of trade that is unavoidable by all countries, as well as an effort to respond to the globalization of the world economy. A Free Trade Area (FTA) is a form of a free trade agreement that is established among one or more countries to create an area of free trading, wherein the trade of goods or services among them may occur past the boundaries of the respective countries without being impeded by imposed tariffs or non-tariff barriers. Next, a Customs Union is fundamentally an FTA that carries external tariff policies that apply to member countries that wish to create trade policies with outside parties. As such, in addition to being an agreement to remove trade barriers, whether those in tariff or non-tariff forms, as well as to eliminate customs duties, a Customs Union creates a single policy for external tariffs (tariffs that apply for countries that are not members of the FTA).

${ }^{41}$ Ibid.
${ }^{42}$ Ibid. 
The formation of the ASEAN Free Trade Area (AFTA) within 15 years had been agreed upon in the fourth ASEAN Summit in Singapore in 1992, and the Common Effective Preferential Tariff (CEPT) Agreement, which constitutes the primary mechanism of the AFTA, had been signed by the Ministers of Economies of ASEAN on January 28, 1992. Even so, the economic integration in ASEAN is not the integration that has been realised in the area of the European Union in recent times and does not merely copy the steps taken by the European Economic Community. At the ASEAN Summit in 2003 in Bali, the leaders of ASEAN stressed that the economic integration to be achieved would not lead ASEAN into a political unification, which means there will be no supranational institutions such as the European Commission, and will also not make customs systems to be uniform (a customs union).

In principle, what is contained in the AFTA is the removal of tariff and non-tariff barriers among ASEAN member countries in a gradual manner through the CEPT Agreement. During the sixth ASEAN Summit in December 1998, there had been an agreement to accelerate AFTA to be realized in 2002 (2006 for Vietnam, 2008 for Laos and Myanmar, and 2010 for Cambodia) with tariffs that range from $0-5 \%$. This acceleration is implemented with several "flexibilities", wherein the condition that the six ASEAN member countries are ready to reduce tariffs of several products to $0-5 \%$ in 2002 , this may be performed in $2003 .{ }^{43}$ In 2003, the products involved in the AFTA must have tariffs with a maximum of $5 \% .44$

In addition, AFTA also contains agreements of tariff harmonization among the member countries of ASEAN, but each country is free to determine tariffs of trading with non-ASEAN member countries. As such, several things need to be performed, in particular in relation to harmonization in the field of custom sand removal of other forms of non-tariff barriers (NTBs). The removal of trade barriers is one of the things that are regulated in competition law.

\section{Conclusion}

The ASEAN Economic Community (AEC) has enabled businesspeople in ASEAN member countries to conduct business transactions in whichever country that they prefer. The aim of the AEC is quite good, which is to ease businesspeople in running their businesses. However, this aim will become a threat if it is not supported by competition laws that can provide clear regulations that apply globally to all businesspeople. Without clear

\footnotetext{
43 Common Effective Preferential Tariff (CEPT), November 21, 2019. https://www.usasean.org/regions/asean/afta/common-effective-preferential-tariff.

${ }^{44}$ See Agreement on the Common Effective Preferential Tariff Scheme for the ASEAN Free Trade Area. 
regulations, businesspeople may freely engage in cross-border transactions that may disrupt the domestic markets of each ASEAN member country.

The existing differences in regulatory substances and the void in competition law regulations in several ASEAN member countries will certainly become challenges for the application of competition laws by businesspeople in the ASEAN regional market. However, regarding AFTA, the primary urgency is instead the realization of imposing tariffs of $0-5 \%$, by performing harmonization of regulations in the field of Customs and the removal of other forms of Non-Tariff Barriers (NTBs). The removal of barriers to trade is one of the things that are also regulated in competition law.

\section{References}

Agreement on the Common Effective Preferential Tariff Scheme for the ASEAN Free Trade Area.

Anggraini, A.M. Tri. "The Mechanisms of Detecting and Uncovering Cartels in Competition Law." Faculty of Law Paper. University of Indonesia, (2011).

Anggraini, A.M. Tri. Larangan Praktik Monopoli dan Persaingan Tidak Sehat: Per se Illegal atau Rule of Reason. Jakarta: Postgraduate, Faculty of Law, University of Indonesia, 2003.

Anonymous, AAMN Objects to the KPPU Verdict: AAMN Considers KPPU to Have Misapplied the Law in the Premier League Broadcasting Rights Case", http://www.hukumonline.com/berita/baca/hol20246/aamnajukan-keberatan-putusan-kppu.

ASEAN. ASEAN Economic Community Blue Print. Jakarta: ASEAN Secretariat, 2015.

Guide on Article 5 on Price Agreements.

Happy Rayna Stephany, Courts Are Still "Allergic" to Indirect Evidence. http://www.hukumonline.com/berita/baca/lt5398841721bba/pengadila n-masih-alergi-dengan-iindirect-evidence-i.

http://nasional.kontan.co.id/news/ma-tolak-putusan-kppu-atas-kartelminyak-goreng.

https://babe.news/id-id/read/9342514/bukti-tidak-langsung-yang-bikin-kpputidak-bertaji.

Ibrahim, Jhonny. Business Competition Law: Philosophy, Theory, and Implications of Implementation in Indonesia. Malang: Bayu Media, 2007.

Khemani, R. Shyam. A Framework for the Design and Implementation of Competition Law and Policy. Washington D.C, Paris: The World BankOECD, 1999.

Komisi Pengawas Persaingan Usaha. Kompetisi Menuju Pasar Bebas ASEAN, $42^{\text {nd }}$ Edition. Jakarta: KPPU, 2013.

KPPU Verdict Number 03/KPPU-L/2008. 
KPPU Verdict Number 07/KPPU-L/2000.

KPPU Verdict Number: 17/KPPU-I/2010.

Kusumaatmadaja, Mochtar. "Harmonisasi Hukum Negara-Negara ASEAN dalam Rangka AFTA dan Harmonisasi Hukum Perdagangan." Jurnal Hukum 1, No. I (1994). https://doi.org/10.20885/iustum.vol1.iss1.art7.

Law No. 5 of 1999 on the Prohibition of Monopolistic and Unhealthy Business Competition Practices.

Lee, Cassey, Yoshifumi Fukunaga. "ASEAN Regional Cooperation on Competition Policy." Journal of Asian Economics, (2014).

Lubis, Andi Fahmy. Anggraini, A.M. Toha, Tri Kurnia. Kagramanto, L. Budi. Hawin, M. Sirait, Ningrum Natasya. Sukarmi. Maarif, Silalahi, Syamsul Udin. (2009). Persaingan Usaha antara Teks dan Konteks Indonesia: Published and Printed with Support of Deutsche Gesellschaft für Technische Zusammenarbeit (GTZ) GmbH.

Malaysian Competition Act of 2010.

Nur, Deswin. "The Unique Merger Regulations in Southeast Asia." Jurnal Kompetisi 24, (2010).

Pangestu, Mari Elka. "Competitiveness Towards ASEAN Economic Community", Journal of Indonesian Economy and Businesss 24, No. 1 (2009).

Pasierbiak, Pawel. "Causes, Origins and Possible Effects of the ASEAN Economis Community(AEC)." Journal of ASEAN Studies 6, No. 1 (2018). https://doi.org/10.21512/jas.v6i1.3897.

Rini Setyastuti, Sri Adiningsih, and Tri Widodo. "Theoretical Versus Practical

Economis Integration.” MPRA Paper No. 86919, (2018).

Singapore Competition Act of 2005.

Sirait, Ningrum N. Hukum Persaingan di Indonesia: UU No. 5/1999 tentang Larangan Praktek Monopoli dan Persaingan Usaha Tidak Sehat.

Cetakan I. Medan: Pustaka Bangsa Press, 2004.

Supreme Court Verdict Number 496/K/Pdt.Sus/2008.

Susilo, Yuvensius Sri. "ASEAN Economic Community Implementation And Indonesian Textile Industry Competitiveness." Economis Journal of Emerging Markets 5, No. 2 (2013), https://doi.org/10.20885/ejem.vol5.iss2.art5.

Tanaka, Andy. "Reformulation of Usage of Single Economic Entity Doctrine in Business Competition Law in Indonesia." Unpublished Thesis, Faculty of Law of the University of Brawijaya, (2016).

Thailand Trade Competition Act B.E. 2542, 1999.

Vietnam Competition Law No. 27/2004/QH11.

Wibowo, Wahyudi. "The Prospects of ASEAN Economic Community." Journal of Economics, Business, and Accountancy Ventura 16, No. 2 (2013).

Widhiyanti, Hanif Nur. "The Use of Indirect Evidence in Proving Suspected Violations of Law Number 5 of Year 1999 in the Perspective of 
Supreme Court Regulations, Number 3 of Year 2005." DPP/SPP Research. Faculty of Law, University of Brawijaya, (2017). 
